\title{
A Psychological Approach to the Scientific Study of Welfare
}

\author{
María Fernanda Enríquez-Villota \\ Universidad Mariana, Pasto, Colombia \\ Email: mariafernandaev@hotmail.com, menriquez@umariana.edu.co
}

How to cite this paper: Enríquez-Villota, M. F. (2019). A Psychological Approach to the Scientific Study of Welfare. Psychology, 10, 1065-1075.

https://doi.org/10.4236/psych.2019.107069

Received: April 8, 2019

Accepted: June 23, 2019

Published: June 26, 2019

Copyright $\odot 2019$ by author(s) and Scientific Research Publishing Inc. This work is licensed under the Creative Commons Attribution International License (CC BY 4.0).

http://creativecommons.org/licenses/by/4.0/

\begin{abstract}
The main objective of this bibliographic research is to approach theoretically the concept of science in psychology by describing the underlying elements of the psychological trends until the emergence of the welfare construct as the principal axis of analysis. The methodology included a review of literature oriented to gathering relevant information about philosophy of science, psychological trends and the concept of welfare. The data gathering process involved updated printed as well as digital sources that were analyzed systematically. As a result, it can be concluded that the research interest on approaching the psychological welfare comes from Ancient Greece and its most salient thinkers. Nonetheless, this interest has constantly evolved going through various theoretical proposals derived from the humanistic psychological trend up to the salutogenic psychology and with it to the positive psychology, which is a contemporary aspect that has as central object of study the concept of welfare. Such concept is understood as the set of evaluative judgments and emotional reactions with regards to the extent to which life experiences are satisfactory, agreeable and positive.
\end{abstract}

\section{Keywords}

Science, Psychological Trend, Welfare

\section{Introduction}

According to Rivadulla (2004), what is known as science is a category proposed by the Greeks that with the evolution of time has experienced changes in its definition. Even the image of science, its possibilities and limits, have changed considerably in recent centuries. Moving from Comte's logical positivism, to Popper's reactionary and scientific response that sought to give rigor to science through the theory of falsification, at the same time, Popper's own realistic con- 
ception of science would later suffer considerable wear by Quine, Kuhn and Feyerabend, who emphasize the conception of science as a dynamic cognitive structure that arises and develops within a social-historical context, a paradigm, constituted by a set of cognitive values that depend on the scientific community (Pérez-Ransanz, 1999).

Finally, the danger of relativism would be conjured thanks to new neopragmatic tendencies in scientific thought, which, recovering ideas already established by Durkheim, Dewey, James and others, would discard the image of science as a mirror of nature, while consolidating it as a rational theory.

In this sense, it is evident that the conception of science is dynamic, constantly changing and deeply rooted in the historical moment in which it develops, and its evolution will be undeniably linked to the prevailing interests of the time.

From this perspective, the particular objective of this article is to present a brief description of the evolution of the concept of science in the particular case of psychology, as well as a basic description of psychological currents, to the point of identifying the scientific origins of the study of welfare as a central category of analysis.

In its historical evolution, psychology has been approached with greater impetus to the understanding of the factors that lead the human being to experience well-being, and the study of this concept has evolved from a pathologizing vision on human behavior towards a positive perspective oriented to the analysis of the elements that lead people to approach this state. According to Vázquez, Hervás, Rahona and Gómez (2009), the efforts to understand this phenomenon and its causes have always had interest in the history of mankind, since from the medical, psychological, political, social and economic perspectives, it is pursued the purpose of increasing the quality of life of people and with it the well-being, as Taylor, Kemeny, Reed, Bower and Gruenewald (2000) point out, positive feelings towards oneself, feelings of personal control and optimistic vision of the future, constitute valuable resources to face life and even, the threatening situations of someone's existence.

\section{Methodology}

For the development of this article, it was applied the methodology of the documentary review that aimed at gathering relevant information about the philosophy of science, psychological currents and the origin of the study of welfare. For the data gathering process, updated printed and digital sources were used, which are accepted by the academic community. Databases such as Scielo, Redalyc, Psicodoc, Proquest, Ebsco, Elibrary and Scopus were used to track information. Basic research was done, in which the ideas and theories of different authors were compared. There were selected those documents that reported on the most important and formal aspects and accepted by the academic community around the subject in question.

In the process of organizing the information collected, the following stages 
were considered: 1) Familiarization with the content of the document or series of documents, 2) Preliminary classification of the documents based on their content and organizational criteria (first evaluation), 3) Selection and extraction of relevant or outstanding information and 4) Verification of concepts or data in individual extracts (second evaluation). Subsequently, the synthesis and final organization of the data was done through ordering and combination of the extracted information within each sub-heading or proposed sub-heading, the comparative evaluation of the different elements or data (third evaluation), and finally, the condensation of the information was carried out in a structure and accessible form according to the objectives and sources worked on. In this sense, an initial tracking of the information in the databases and printed documents identified through the keywords of the research (science, psychological trend, and welfare) was carried out. Then, relevant information was classified taking into account criteria such as theoretical strength of the document, contributions to the objectives of the documentary review, and updating of the information, after that, the relevant information to the purposes of the analysis was selected within each document, and finally an exercise of contrast and organization of the collected data was done. Now, the main theoretical findings of the researched documents are presented in a synthetic way.

\section{Results and Discussion of Literature Review}

\subsection{An Outline of the Concept of Science}

From the perspective of Santiago, Mora and Rosero (2017), the concept of science in the classical paradigm is true and evident knowledge of things by their causes and this is a type of specialized knowledge of mathematics and philosophy. Later, the authors point out that empirical knowledge becomes relevant and after the Copernican turn it is more accurate understanding of science from experimentation or rational demonstration and that is, where physics is constituted as a science model that reaches its status in the sixteenth century with Newton. In the nineteenth century, the positivism was consolidated with Comte and Stuart Mill with the predominance of the scientific method applied to all types of sciences. As a reactionary response to this position arises a new paradigm of study of the social sciences raised by Dilthey, Weber, Simmel and Croce who suggest that while the goal of the natural sciences is to explain, the goal of the social sciences is to understand human phenomena.

In this sense, from the perspective of Marx and Engels around their reflections on historical materialism, it is denounced that science had forgotten the study of the human being as a specific subject located historically, culturally and politically, which is why technologization gradually displaced the workforce replacing it with scientific advances of the moment. From this perspective, science responds to a constant instrumentalization contributing to the growth of capitalism and does not put itself at the service of humanity (Gómez, 2008).

Likewise, from dialectical materialism arises the need of analyzing the dialo- 
gicity between science, history, culture and human being. And it is here, where it is proposed the interest of rethinking science as a "human benefit" to avoid the estrangement of the human being.

On his part Bunge (1996) suggests that in the history of humanity, science has sought to dominate nature through formal and factual forms of knowledge that use research and the scientific method to transform reality. And it is at this point that new technologies become an important resource to achieve this domination. Of course, these ideas of technological order on the conception of science are opposed to Dilthey's bets and his more comprehensive vision of science in the field of humanities.

And it will be at the beginning of the 20th century that scientific reflections become more complex around three important scientific revolutions; the quantum theory of Max Plank in 1900; Einstein's theory of relativity in 1905 and Heisemberg's theory of uncertainty principle in 1927. From these new perspectives, science has been questioned, relativized and deeply complexed and today more than ever, the "doubt" will continue to be the guiding principle of the development of science's philosophy.

\subsection{Science and Psychology}

In what refers to psychology, since long time ago it is possible to trace some antecedents and scientific interests around the analysis of the psyche, or study of the mind. Various philosophical conceptions of Greek culture with the contributions of Socrates and his premise "know yourself", Plato and his concept of the "rational soul" and Aristotle with his conception "soul-body" will influence notably psychological postulates developed later.

Lafuente, Loredo and Tejerina (2017) point out that the origin of psychology as a scientific discipline dates back to the end of the 19th century, in Germany, with the establishment of the first psychology laboratory in Leipzig, in 1879, by Wilhelm Wundt. This event is considered the foundational myth of psychology because it makes use of the experimental method in which Wundt had been formed during his previous investigations in the field of physiology, with scientists like Johannes Müller and Hermann Von Helmholtz giving it the defining feature to scientific psychology.

From there, a series of attempts to measure mental processes happened, with the subsequent debates about the possibility of empirical-experimental psychological research. Since then, psychology will go through several currents of thought that will establish the way in which it is investigated, the concepts and methods that are used to work and the objective pursued when building knowledge.

In fact, Myers (2007) states that the variety of theoretical and practical proposals about the scientific direction of psychology has been surprisingly large, it begins with the current structuralism that appeared around 1890 that includes the members of the tradition of psychological research inaugurated by Wilhelm 
Wundt and represented later by Edward Titchener for whom the goal of psychology must be to discover the basic elements of consciousness and the way in which they interact with each other to create mental processes.

According to Mestre (2006), further on, at the beginning of the 20th century, Functionalism emerged, a current that proposes a rejection of structuralism, since, instead of focusing on studying the components of the mind, it aimed to understand the functioning of mental processes, that is, psychological functions.

According to Valera (2008), the consolidation of capitalism with the development of its superior phase, imperialism, created right socio-economic conditions to the development of psychological science, since knowing the psychic functioning of the man to achieve its adaptation to the new products of the technical-scientific revolution and submit it to the designs of the new and powerful political system was an urgent need (p. 5).

Another current is the psychoanalysis that appears in the last years of the nineteenth century with the work of Sigmund Freud based on the study of psychic structure and unconscious processes.

Shortly after, behaviorism was consolidated, being a current of psychology that refused the proposals of Freud and his followers, but also many other researchers with a tendency towards mentalism. Contrary to it, behaviorism emphasized the importance of basing research on human behavior on observable and measurable elements, avoiding unjustified speculation to the maximum and fleeing from the interpretation of acts in a symbolic way.

From the behavioral perspective, the object of study of psychology should be the behavior, and not mental processes, its most prominent representatives were Watson and Skinner according to Peña Correal (2010).

For Tortosa and Civera (2006), the psychological current called Gestalt was born in Germany, it is oriented to study psychological processes related to perception and the way in which solutions to new problems are found, from this current the laws of Gestalt, through which the processes by which the brain creates information units qualitatively different from the data that come through the senses, were described.

According to Cambaúva, Silva and Ferreira (1998) in the second half of the $50 \mathrm{~s}$ and the beginning of the $60 \mathrm{~s}$, a reaction to the dominant mechanism of behaviorism and psychoanalysis was born with the emergence of two new currents of study, being these, Humanistic Psychology and Cognitive Psychology, the latter understands the human being as someone who participates actively in the construction of his experience and therefore of knowledge.

On the other hand, Humanistic Psychology, which was born in the United States as a "third force" together with behaviorism and psychoanalysis, expresses a holistic orientation in the understanding of human behavior. According to Gallegos (2016), from this perspective, a marked interest in the global consideration of the person is promulgated, while promulgating a strong disaffection for the naturalistic model in the field of psychology. Its formal constitution is produced in 1961, standing out as representatives Rogers, Maslow, Buhler and May. 
These authors and especially Rogers take up Husserl's phenomenology in which it is considered as a fundamental element of psychological analysis the intentionality of consciousness, the experience, and the subjective experience. We return to the existential philosophy from where it is understood that the being or core of the personality changes, it is dynamic and tends to self-actualization. Therefore, from this perspective, what is sought from psychology is the development of human potential.

Taking into account what has been stated so far, the study of the person situated existentially in which his individual experience and uniqueness are fundamental and constitute the scientific background of the psychological well-being concept, center of interest of this article and which is described in greater detail below.

\subsection{Science and Welfare}

The study of the welfare concept appears since the ancient Greeks with the proposals of Democritus and his thoughts about the pleasure and the harmony in life; Cicero and his proposal of not left yourself absorb by pain; Heraclitus and his concept around the perpetual flow, today related to the concept of flow; Seneca and his postulates around happiness and virtue; and going deeper, with the proposal of the "Aristotelic Eudaimonia" referred to the analysis of happiness, the human flourishing or the prosperity, or the existential analysis of what limits to reach that ideal.

Since Aristotle and the ancient thinkers' point of view, but also Saint Agustin and his proposal about the virtue; Saint Thomas and his analysis of the healthy personality; Spinoza and his happiness comprehension in the God and men framework; Schopenhauer and his reflections about the existentialism since the consideration of the experiences of the individual that define subjectively his affective states and with this, his happiness; Heidegger who analyses the relation man-world and world-man and since then, he develops existential thoughts about the human subjectivity with the perspective of the being in the world; thinkers who have developed these reflections about happiness and welfare constitute one of the central axes of the thinking about the human (Vázquez, 2006; Fernández-Ríos, 2008).

According to Casullo (2000) in the field of psychology, the interest about the positive aspects of human psychism dates back to the origins of the Norte American academic psychology, there, the writings of William James about the "healthy mind" became important, but is in the decade of 1980 that the emergence of the concept of health promotion emerges, this concept anticipates the arrival of the healthgenic approach in the field of social sciences. At the same time, healthgenic or positive psychology is defined as a new paradigm of theorical and methodological reflection. There, it is possible to highlight the contributions of Allport with his reflections about how the human being through his experiences shows his subjective states and his attitude towards life, and the representatives of the Humanist Psychology whose main thinkers validate the concept 
of psychic health to the development of the potentialities of the psychism as Maslow, Jahoda, Erikson, Vaillant, Ryff, Singer and particularly Rogers with his proposal about the full operation of people (Lupano \& Castro, 2010).

In second term, the named independent research about the functional aspects of psychism as: resilience, creativity, multiple intelligences, emotional intelligence, attachment theory, among others are antecedents of the development of the positive psychology and therefore precursors of the study of the welfare concept. Also, since the healthgenic orientation proposed by Aaron Antonovsky from the field of the sociology of the medicine where health/sickness is understood as the ends of a continuum and his interest to study those factors that promote movements through the favorable end of itself, constitute the events that marked the beginning of the positive psychology and with it the study of the welfare (Gancedo, 2008; Mariñelarena-Dondena \& Gancedo, 2011).

However, it was Martín Seligman in 1998 in his inaugural speech as a president of the American Psychological Association (APA), the event that gave scientific status to the study of the positive psychology in charge of analyze the positive qualities that all human beings have and how to potentiate them through interventions based on empirical evidence (Seligman, Steen, Park, \& Peterson, 2005). According to Mariñelarena-Dondena (2012) since that event, Seligman says that positive psychology should focus on the study of welfare.

Nevertheless, this important psychological construct has gone through different perspectives, starting from Greek thinkers as it was pointed before, and then to contemporary conceptions as the proposed by Jahoda in 1958 about the concept of mental health, who according to Hervás (2009) conducts a pioneer work regarding this concept when presenting a model in which the characteristics that define a positive health mental state would be defined, this model allows to identify six domains that are: attitudes towards oneself, growth and self-updating, integration, autonomy, perception of the reality and domain of the environment (Muñoz, Restrepo, \& Cardona, 2016).

This model worked as inspiration for a most current model and of great expansion as the developed by Ryff (1989), since this perspective the welfare is considered as the reflection of an optimal psychological working. In consequence, he suggests that the balance between the positive and negative emotions can be independent of the welfare and proposes six basic dimensions that limit it as: self-acceptance, positive relationships, autonomy, domain of the environment, purpose in life, and personal growth. Also, defines the two ends of welfare, on one side, the optimal working, and in the other, the deficient working.

According to Hervás (2009) in a further moment Keyes proposes a model of the welfare dimensions that includes as its main innovation which he names social welfare, which is based on the satisfaction of the individual with his cultural and social environment. It evaluates the components that go further the satisfaction of a person with himself, his future or immediate resources, to focus on the perceived quality from the society around him. According to the author, there would be five different dimensions in the field of social welfare: social coherence, 
social integration, social contribution, social updating and social acceptance.

Recently, Casales (2004) says that in the definition of welfare there are basically four theoretical perspectives: 1) the ecologist approach, that studies and analyses the relationship between people and the physical spaces around them; 2) the economic approach, that focuses on the income level, social spending and individuals or contemplated communities' investment; 3) the sociological approach, referred to the set of objective and observable conditions that constitute a community; and 4) the psychosocial approach, that contemplates the interaction of the perception of oneself and the world around, which means the building of resources against the difficulties and conflicts of the everyday reality also named as psychosocial welfare.

In this horizon, Lazarus and Folkman (1984) develop a psychosocial theoretical model to explain the welfare. For them, welfare depends on the type of coping issued by each person. In this way, the model of transactional coping stops in the cognitive and behavioral efforts made by the individuals to manage internal and external demands. In this sense, the coping and therefore the welfare are determined by the person, the environment and also the interaction (González, Montoya, Casullo, \& Benabéu, 2002).

It is also possible to appreciate the model proposed by Sánchez-Cánovas (1998) for whom the psychological welfare makes reference to the sense of happiness or welfare, which is a subjective perception of the own life. The author integrates different factors which together give a result of the psychological welfare as a global construct that includes material aspects referred to material welfare and on the other side psychological aspects that corresponds to the subjective welfare.

Blanch, Cervantes, Cantera, \& Sahagún (2010) indicate that in this moment, the study of welfare constitutes a primary theorical referent, from the moment in which the World Health Organization uses it, in his constitutional declaration of 1984, and presents it as the cornerstone of its health definition as a "whole state of physical, psychological and social welfare".

Also, authors point out the renewed focus of the World Health Organization in 1981 about the health promotion as welfare and not only as the absence of discomfort, in its global strategy of "Health for everyone" generated in 2000 and in successive proposals about sanitary politics that have followed it, and that have pushed the emergence of multiple theoretical comprehensions about the topic.

Blanch et al. (2010) also indicate, that in terms as welfare, happiness, satisfaction, health and even optimism, flow and expressions as the ones of mental health, life quality or optimal experience have been used sometimes as synonyms and interchangeable, clarifying that the same happens with expressions as subjective welfare and psychological welfare. From here that welfare can be defined as a group of value judgements and emotional reactions concerning the grade in which the own experience is lived as satisfying, pleasant and positive (Andrews 
\& Withey, 1976; Diener, Suh, Lucas, \& Shmit 1999; Diener, Oishi, \& Lucas, 2003).

Taking into account this general view around the study of the welfare concept it is possible to say that the scientific interest to think about this important construct comes from the ancient Greece and its main thinkers. However, this interest has evolved in a continuous way going from theoretical proposals coming from the humanistic psychological trend, to the healthgenic psychology and with it the positive psychology, contemporary side that has delimited as its own object of study the concept of welfare.

\section{Conclusion}

The concept of science has evolved historically, going from the classical thoughts, to the Copernicus proposals, then, the positivists assumptions in contrast with the criticism of Dilthey, and finally to the current questioning proposed by Max Plank, Einstein and Heisemberg, which certainly contribute to keep questioning the concept of science and lead the way in its evolution with their statements.

Talking about the concept of science in psychology, it is possible to appreciate that its transformation is moved since the ancient Greek thinkers, then to Wundt and the emergence of the first psychology laboratory, from which the scientific study of the human behavior becomes the cornerstone of the psychological progress.

The definition of science in psychology has gone from important currents of thought as the structuralism, the functionalism, the psychoanalysis, the behaviorism, and the cognitive psychology, to recently the humanism that has derived in new sides as the healthgenic and positive psychology that has as a main subject of studying the welfare concept.

Talking about the scientific study of the welfare, it is possible to see its background in the Greek thinkers and particularly in Aristotle's thoughts around the eudaimonia. However, its development is related to the thoughts of humanism psychologist such as Roger and Maslow and the contributions of Jahoda and Seligman, then fed by more recent research by Riff and Keyes until getting to the assumptions of Blanch and contemporary authors that define it as the set of value judgements related to the degree in which the own experience is perceived as satisfactory.

\section{Conflicts of Interest}

The author declares no conflicts of interest regarding the publication of this paper.

\section{References}

Andrews, F., \& Withey, S. (1976). Los indicadores sociales de bienestar: La percepción de la calidad de vida de estadounidenses. New York: Plenum.

Blanch, J., Cervantes, G., Cantera, L., \& Sahagún, M. (2010). Cuestionario de Bienestar 
Laboral General: Estructura y Propiedades Psicométricas. España: Revista de Psicología del Trabajo y de las Organizaciones, 26, 157-170.

http://colpos.redalyc.org/articulo.oa?id=231316500007 https://doi.org/10.5093/tr2010v26n2a7

Bunge, M. (1996). Sociologías del conocimiento: Científicas y anticientíficas. Argentina: Redes, 3, 125-128.

Cambaúva, L., Silva, L., \& Ferreira, W. (1998). Reflexões sobre o estudo da História da Psicología. Brasil: Estudos de Psicología, 3, 207-227. https://doi.org/10.1590/S1413-294X1998000200003

Casales, J. (2004). Psicología Social. La Habana: Editorial Félix Varela.

Casullo, M. (2000). Psicología salugénica o positiva. Algunas reflexiones. Argentina: Anuario de Investigaciones. Facultad de Psicología. Universidad de Buenos Aires, 340-346.

Diener, E., Oishi, S., \& Lucas, R. (2003). Personalidad, Cultura y bienestar Subjetivo. Las evaluaciones cognitivas y emocionales de la vida. Revista anual de Psicología, 54, 403-425.

Diener, E., Suh, M., Lucas, E., \& Smith, H. (1999). Bienestar subjetivo. Tres décadas de progreso. Boletín Psicológico, 125, 276-302. https://doi.org/10.1037//0033-2909.125.2.276

Fernández-Ríos, L. (2008). Una revisión crítica de la psicología positiva: historia y concepto. Colombia: Revista Colombiana de Psicología, 17, 161-176.

Gallegos, M. (2016). Historia de la Psicología y Formación en Psicología en América Latina: Convergencias Temáticas. México: Enseñanza e Investigación en Psicología, 21, 319-335.

Gancedo, M. (2008). Historia de la Psicología Positiva. Antecedentes, aportes y proyecciones. In M. M. Casullo (Ed.), Prácticas en Psicología Positiva (pp. 11-38). Buenos Aires: Lugar Editorial.

Gómez, R. (2008). Materialismo y Dialéctica. La Supervivencia de Marx a Inicios del Siglo XXI. México: Bajo el Volcán, 7, 137-152.

González, R., Montoya, I., Casullo, M., \& Bernabéu, J. (2002). Relación entre estilos y estrategias de afrontamiento y bienestar psicológico en adolescentes. España: Psicothema, 14, 363-368.

Hervás, G. (2009). Psicología positiva: una introducción. España: Revista Interuniversitaria de Formación del Profesorado, 23, 23-41.

Lafuente, E., Loredo, J., \& Tejerina, J. (2017). Historia de la psicología, UNED-Universidad Nacional de Educación a Distancia. ProQuest Ebook Central. http://ebookcentral.proquest.com/lib/umarianasp/detail.action?docID=482427

Lazarus, R. S., \& Folkman, S. (1984). Estrés, valoración y afrontamiento. Nueva York: Springer.

Lupano, M., \& Castro, A. (2010). Psicología Positiva: Análisis desde su surgimiento. Ciencias Psicológicas, 4, 43-56. http://www.scielo.edu.uy/pdf/cp/v4n1/v4n1a05.pdf

Mariñelarena-Dondena, L. (2012). Surgimiento y Desarrollo de la Psicología Positiva. Análisis desde una historiografía crítica. Psicología, Cultura y Sociedad, 12, 9-22. https://doi.org/10.18682/pd.v12i0.364 https://dspace.palermo.edu/ojs/index.php/psicodebate/article/view/364

Mariñelarena-Dondena, L., \& Gancedo, M. (2011). La Psicología Positiva: su primera década de desarrollo. Diálogos. Argentina: Revista Científica de Psicología, Ciencias 
Sociales, Humanidades y Ciencias de la Salud, 2, 67-77.

Mestre, M. (2006). Revista de Historia de la Psicología. España: Revista Latinoamericana de Psicología, 38, 631-632.

Muñoz, C., Restrepo, D., \& Cardona, D. (2016). Construcción del concepto de salud mental positiva. Revisión sistemática. Colombia: Revista Panamericana de Salud Publica, 39, 166-173.

Myers, D. (2007). Psicología. Editorial Médica Panamericana.

Peña Correal, T. (2010). ¿Es Viable El Conductismo en el siglo XXI? Perú: Liberabit. Revista de Psicología, 16, 125-130.

Pérez-Ransanz, A. (1999). Kuhn y el cambio científico. México: Fondo de Cultura Económica.

Rivadulla, A. (2004). Filosofía de la Ciencia Hoy: Problemas y Posiciones. Madrid: Editorial Trotta. Revista de Teoría, Historia y Fundamentos de la Ciencia, 21, 113-114.

Ryff, C. D. (1989). Happiness Is Everything, or Is It? Explorations on the Meaning of Psychological Well-Being. Journal of Personality and Social Psychology, 57, 1069-1081. https://doi.org/10.1037//0022-3514.57.6.1069

Sánchez-Cánovas, J. (1998). Escala de Bienestar Psicológico. Madrid: Editorial TEA Ediciones, S. A. U; Fray Benardino Sahagún, 24-28036.

Santiago, D., Mora, F., \& Rosero, V. (2017). Filosofía y Psicología: Hacia una Reflexión Latinoamericanista. Colombia: Editorial Unimar.

Seligman, M., Steen, T., Park, N., \& Peterson, C. (2005). Positive Psychology progress: Empirical validation of interventions. American Psychologist, 60, 410-421. https://doi.org/10.1037/0003-066X.60.5.410

Taylor, S., Kemeny, M., Reed, G., Bower, J., \& Gruenewald, T. (2000). Psychological Resources, Positive Illusions, and Health. American Psychologist, 55, 99-109. https://doi.org/10.1037/0003-066X.55.1.99

Tortosa, F., \& Civera, C. (2006). Historia de la psicología (1st ed.). Ebookcentral. https://ebookcentral.proquest.com

Valera, O. (2008). Las corrientes de la psicología. Cuba: Editorial Pueblo y Educación.

Vázquez, C. (2006). La Psicología Positiva en perspectiva. En Papeles del Psicólogo, 27, $1-2$.

Vázquez, C., Hervás, G., Rahona, J., \& Gómez, D. (2009). Bienestar psicológico y salud: Aportaciones desde la Psicología Positiva. Anuario de Psicología Clínica y de la Salud, 5, 15-28. http://institucionales.us.es/apcs/doc/APCS_5_esp_15-28.pdf 